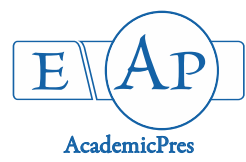

\title{
Pharmacological Uses and Health Benefits of Ginger (Zingiber officinale) in Traditional Asian and Ancient Chinese Medicine, and Modern Practice
}

\author{
Mohamad Hesam SHAHRAJABIAN ${ }^{1,2}$, Wenli SUN ${ }^{1,2}$, Qi CHENG ${ }^{1,2 *}$ \\ ${ }^{1}$ Chinese Academy of Agricultural Sciences, Biotechnology Research Institute, Beijing 100081, China \\ ${ }^{2}$ Qi Institute, Nitroegn Fixation Laboratory, Building C4, No. 555 Chuangye County, Jiaxing 314000, Zhejiang, \\ China; hesamshahrajabian@gmail.com; sunwenli@caas.cn; chengqi@caas.cn (*correspondingauthor)
}

\begin{abstract}
Ginger (Zingiber officinale) has been used as a spice and a medicine for over 200 years in traditional Chinese medicine. Ginger is an important plant with several medicinal and nutritional values used in Asian and Chinese tradition medicine. Ginger and its general compounds such as $\mathrm{Fe}, \mathrm{Mg}, \mathrm{Ca}$, vitamin $\mathrm{C}$, flavonoids, phenolic compounds (gingerdiol, gingerol, gingerdione and shogaols), sesquiterpenes, paradols has long been used as an herbal medicine to treat various symptoms including vomiting, pain, cold symptoms and it has been shown to have anti-inflammatory, anti-apoptotic, anti-tumor activities, anti-pyretic, anti-platelet, anti-tumourigenic, anti-hyperglycaemic, antioxidant anti-diabetic, anti-clotting and analgesic properties, cardiotonic, cytotoxic. It has been widely used for arthritis, cramps, sprains, sore throats, rheumatism, muscular aches, pains, vomiting, constipation, indigestion, hypertension, dementia, fever and infectious diseases. Ginger leaves have also been used for food flavouring and Asian traditional medicine especially in China. Ginger oil also used as food flavouring agent in soft drink, as spices in bakery products, in confectionary items, pickles, sauces and as a preservatives. Ginger is available in three forms, namely fresh root ginger, preserved ginger and dried ginger. The pharmacological activities of ginger were mainly attributed to its active phytocompounds 6-gingerol, 6-shogaol, zingerone beside other phenolics and flavonoids. Gingerol and shogaol in particular, is known to have anti-oxidant and anti-inflammatory properties. In both traditional Chinese medicine, and modern China, Ginger is used in about half of all herbal prescriptions. Traditional medicinal plants are often cheaper, locally available and easily consumable raw and as simple medicinal preparations. The obtained findings suggest potential of ginger extract as an additive in the food and pharmaceutical industries.
\end{abstract}

Keywords: ginger; modern medicine; pharmacological science; traditional Chinese medicine

\section{Introduction}

Ginger occurrence, cultivation, chemical constituents, nutrient composition and chemical composition

Traditionally, Chinese medicine includes herbal medicines and acupuncture (Akinyemi et al., 2016; Shahrajabian et al., 2018; Ogbaji et al., 2018; Shahrajabian et al., 2019a,b,c,d,e; Shahrajabian et al., 2020). Zingiber officinale is a member of the Zingiberaceae plant family, native to East and southern Asia, consisting of 49 genera and 1300 species, 80-90 of which are Zingiber. Its generic name Zingiber is derived from the Greek zingiberis, which comes from the Sanskrit name of the spice, singabera; the Latin name, Zingiber, means shaped like a horn and refers to the roots, which resemble a deer's antlers (Sharma et al., 2017). The plant is known as Sringavera in Sanskrit (Vasala, 2004). Ginger (Zingiber officinale Roscoe.) has a long history of being used as a medicine and herbal since ancient time and had been used as an important cooking spice throughout the world (Nour et al., 2017). It is a plant that is used in folk medicine from south-east Asia, and in GrecoRoman traditions, Brazil, Australia, Africa, China, India, Bangladesh, Taiwan, Mexico, Japan, Jamaica, the India, the Middle East and parts of the United Sates also cultivate the rhizomes for medicinal purpose (Langner et al., 1998; Blumenthal et al., 2000; Sekiwa et al., 2000; Yadav et al., 2016). El-Sayed and Moustafa (2016) reported that ginger rhizome is widely used as a spice or condiment. For 
310

centuries has been an important ingredient in traditional Chinese medicine, Ayurvedic, and Unani-tibb herbal medicines for the treatment of different diseases (Willetts $e t$ al., 2003; Ali et al., 2008; Memudu et al., 2012). Zingiber officinale was also one of the first oriental spices to be grown to the Europeans, it was introduced to northern Europe by the Romans who got it from Arab traders and was one of the most popular spices in the Middle Ages (Kala et al., 2016). Alakali et al. (2009) also mentioned that ginger was one of the earliest oriental species known in Europe in the $9^{\text {th }}$ century, in the $13^{\text {th }}$ century, it was introduced to East Africa by the Arabs. In West African and other parts of the tropics, it was introduced by the Portuguese in the $16^{\text {th }}$ century (Kochhar, 1981). The spice was known in Germany and France in the ninth century and in England in $10^{\text {th }}$ century for its medicinal properties (Yadav et al., 2016). Elzebroek and Wind (2008) found that Marco Polo, introduced to ginger while visiting China and Sumatra in the $13^{\text {th }}$ century, transported some to Europe. They have also discussed how the cultivation of ginger in Mexico was initiated by the Spaniard, Francesco de Mendoza. In China, dried Ginger, known as Gan-jiang is mentioned in the earliest of herbals, She Nung Ben Cao Jing, attributed to Emperor Shen Nung (almost 2000 BC). Chinese records dating from $4^{\text {th }}$ century $\mathrm{BC}$ indicate that Ginger was used to treat numerous conditions including stomach ache, diarrhea, nausea, cholera, henorrhage, rheumatism, and toothaches. Not only in traditional Chinese medicine, but also in modern China, Ginger is used in about half of all herbal prescriptions, because of its ability to act as messenger, servant and guide herb that brings other herbal medicines to the site where they are needed (Afzal et al., 2001). Ginger cultivation back about 3000 years ago in India, and it remains an integral part of Indian cuisine where it is commonly used in many popular dishes (Daily $e t$ al., 2015). Lister (2003) revealed that the ginger plant has a long history of cultivation known to originate in China and it was one of the most parts of Chinese traditional medicine, and then spread to India, Southeast Asia, West Africa and the Caribbean. In Korea, ginger has been used to season foods for the last 1000 years approximately (Daily et al., 2015). Sliced ginger with sugar added is used to make tea, prickled ginger slices (Gari) are frequently used a condiment in Japan, and ginger is commonly used to flavour cookies and cakes in Western countries.

Zingiber officinale Roscoe classification is Kingdom: Plantae-plants, Subkingdom: Tracheobionta-vascular plants, Superdivision: Spermatophyta-seed plants, Division: Magnoliophyta-flowering plants, Class: LiliopsidaMonocotyledons, Subclass: Zingiberidae, Order: Zingiberales, Family: Zingiberaceae- Ginger family, Genus: Zingiber P. Mill - Ginger, Species: Zingiber officinale Roscoe- Garden ginger. Red Ginger (Z. officinale var. rubra) is a variance of the Zingiber officinale species cultivated in Indonesia and Malaysia. Moreover, having gingerols and shogaols, it is loaded with anthocyanin and tannin in its root bark. Traditionally, it is used in species, syrup and as remedy for rheumatism, osteoporosis, asthma and cough. Some of the country grows with variation in species viz: Indian, Nepal, Bangladesh, Sri Lanka ginger - (Zingiber officinale), Jamaican ginger - (Zingiber officinale), Chinese ginger - (Asarum splendens), Australian ginger - (Alpinia caerulea), Nigerian ginger - (Zingiber officinale white and yellow variety), Japanese ginger - (Zingiber mioga), Indonesian ginger - (Alpinia galangal), and Hawaiian Island - (Zingiber zerumbet) (Sandeep, 2017). Common names of Ginger in different countries are, Chinese: Geung, Cook Islands: Kopakai, English: Ginger, Fiji: Cagolaya ni vavalagi, Hawaiian: Awapuhi Pake, India: Adrak and Inchi, Japan: Shoga, Java: San gurng, Gung Guung, San geong, Atjuga, Niue: Poloi, Solomon Islands: Papasa, Spanish: Jengibre, Thailand: Khing, Vietnamese: Gung. Black ginger, the rhizome of Kaempferia parviflora (Zingiberaceae), has traditionally been used as food and a folk medicine for one thousand year in Asian traditional medicine especially in Thailand. The dried rhizome is pulverized and used as tea bags, while fresh one is utilized to brew wine. As dietary supplements, it has been made into various preparations such as medicinal liquor or liquor plus honey, pills, capsules and tablets. It has been claimed that black ginger is appropriate to cure allergy, asthma, impotence, gout, diarrhoea, dysentery, peptic ulcer and diabetes (Toda et al., 2016). Other notable member of this family (Zingiberacea) is turmeric otherwise called red ginger (Curcuma longa) (Akinyemi et al., 2015). It is a rhizomatous herbaceous perennial plant, in the ginger family, employed as a dye source food colorant due to its characteristics yellow colour (Chan et al., 2009).Ginger is a warm-season crop adapted for growth in tropical and subtropical regions. Best growth occurs under moist conditions and temperatures of 25-28 ${ }^{\circ} \mathrm{C}$. Growth efficiency declines with temperatures above 30 ${ }^{\circ} \mathrm{C}$ and below $24{ }^{\circ} \mathrm{C}$. Ginger grows well in full sun. Vegetative growth is promoted with long day lengths, and rhizome enlargement is promoted under shorter day lengths. Ideal $\mathrm{pH}$ is 5.5-6.5 and it requires a deep (25-40 $\mathrm{cm}$ ), rock-free, sandy loam soil, high in organic matter with adequate drainage that allows for proper hilling of the crop. Ginger is usually available in three different forms: 1) Fresh (green) root ginger, 2) Preserved ginger in brine or syrup, 3) Dried ginger spice. Fresh ginger is usually consumed in the area where it is produced, although it is possible to transport fresh roots internationally. Both mature and immature rhizomes are consumed as a fresh vegetable. Preserved ginger is only made from immature rhizomes. Most preserved ginger is exported; Hong Kong, China and Australia are the major producers of preserved ginger and dominate the world market. Dried ginger spice is produced from the mature rhizome. As the rhizome matures the flavour and aroma become much stronger. Dried ginger is exported, usually in large pieces which are ground into a spice in the country of destination. Dried ginger can be ground and used directly as a spice and also for the extraction of ginger oil and ginger oleoresin. The main area under ginger covering is related to Nigeria $56.23 \%$ of the total global area followed by India (23.6\%), China (4.47\%), Indonesia (3.37\%), and Bangladesh (2.32\%) (Dhanik et al., 2017). Top ten Ginger producing country of the world has been shown in Table 1 .

The nutritional composition of Ginger is shown in Table 2; nutritional profile is presented in Table 3 and the active chemical constituents in shown in Table 4. 
Table 1. Top ten Ginger producing country of the world (Dhanik et al., 2017)

\begin{tabular}{cccc}
\hline No. & Country & Production (Tonnes) \\
\hline 1 & India & 683000 \\
2 & China & 25000 \\
3 & Nepal & 235033 \\
4 & Indonesia & 160000 \\
5 & Nigeria & 140000 \\
6 & Thailand & 69000 \\
7 & Bangladesh & 57835 \\
8 & Japan & 46350 \\
9 & Cameroon & 28216 \\
\hline
\end{tabular}

Table 2. Nutritional composition of Ginger (per $100 \mathrm{~g}$ ) (Sandeep, 2017)

\begin{tabular}{|c|c|}
\hline Constituent & Value \\
\hline Moisture & $15.02 \pm 0.04$ \\
\hline Protein $(\mathrm{g})$ & $5.087 \pm 0.09(5.98)$ \\
\hline Fat $(\mathrm{g})$ & $3.72 \pm 0.03(4.37)$ \\
\hline Insoluble fibre (\%) & $23.5 \pm 0.04(30.0)$ \\
\hline Soluble fibre (\%( & $25.5 \pm 0.04(30.0)$ \\
\hline Carbohydrate (g) & $38.35 \pm 0.1$ \\
\hline Vitamin C (mg) & $9.33 \pm 0.08(10.97)$ \\
\hline Total carotenoids $(\mathrm{mg})$ & $79 \pm 0.2(92.96)$ \\
\hline $\operatorname{Ash}(\mathrm{g})$ & $3.85 \pm 0.61(4.53)$ \\
\hline Calcium (mg) & $88.4 \pm 0.97(104.02)$ \\
\hline Phosphorous (mg) & $174 \pm 1.2(204.75)$ \\
\hline Iron (mg) & $8.0 \pm 0.2(9.41)$ \\
\hline Zinc (mg) & $0.92 \pm 0(1.08)$ \\
\hline Copper (mg) & $0.545 \pm 0.002(0.641)$ \\
\hline Manganese (mg) & $9.13 \pm 0.01(10.74)$ \\
\hline Chromium $(\mu \mathrm{g})$ & $70 \pm 0(83.37)$ \\
\hline
\end{tabular}

All value in this table represent the mean $\pm \mathrm{SD}(\mathrm{n}=4)$. Figures in the parenthesis represent the dry weight values (Shirin Adel and Prakash, 2010)

Table 3. Nutritional profile of Ginger (100 g) (Singh et al., 2017)

\begin{tabular}{|c|c|c|}
\hline Types of nutrient & Examples of nutrient & Amount \\
\hline Protein & $+\cdots$ & $1.8 \mathrm{~g}$ \\
\hline Water & -..- & $78.9 \mathrm{~g}$ \\
\hline \multirow[t]{2}{*}{ Phyto-sterols } & $-\ldots-$ & $15 \mathrm{mg}$ \\
\hline & Total Carbohydrate & $18 \mathrm{~g}$ \\
\hline \multirow[t]{4}{*}{ Carbohydrates } & Dietary Fibre & $2 \mathrm{~g}$ \\
\hline & Sugar & $1.7 \mathrm{~g}$ \\
\hline & Total Fat & $750 \mathrm{mg}$ \\
\hline & Saturated Fat & $203 \mathrm{mg}$ \\
\hline \multirow[t]{8}{*}{ Fats and Fatty acids } & Monounsaturated Fat & $154 \mathrm{mg}$ \\
\hline & Polyunsaturated Fat & $154 \mathrm{mg}$ \\
\hline & Omega-3 Fatty Acids & $34 \mathrm{mg}$ \\
\hline & Omega-6 Fatty Acids & $120 \mathrm{mg}$ \\
\hline & Vitamin C & $5 \mathrm{mg}$ \\
\hline & Vitamin E & $260 \mathrm{mcg}$ \\
\hline & Vitamin K & $0.1 \mathrm{mcg}$ \\
\hline & Thiamin & $25 \mathrm{mcg}$ \\
\hline \multirow[t]{10}{*}{ Vitamins } & Riboflavin & $34 \mathrm{mcg}$ \\
\hline & Niacin & $750 \mathrm{mcg}$ \\
\hline & Vitamin B6 & $160 \mathrm{mcg}$ \\
\hline & Folic acid & $11 \mathrm{mcg}$ \\
\hline & Pantothenic Acid & $203 \mathrm{mcg}$ \\
\hline & Choline & $28.8 \mathrm{mg}$ \\
\hline & Calcium & $16 \mathrm{mg}$ \\
\hline & Iron & $600 \mathrm{mcg}$ \\
\hline & Magnesium & $43 \mathrm{mg}$ \\
\hline & Phosphorous & $34 \mathrm{mg}$ \\
\hline \multirow[t]{6}{*}{ Minerals } & Potassium & $415 \mathrm{mg}$ \\
\hline & Sodium & $13 \mathrm{mg}$ \\
\hline & Zinc & $340 \mathrm{mcg}$ \\
\hline & Copper & $226 \mathrm{mcg}$ \\
\hline & Manganese & $229 \mathrm{mcg}$ \\
\hline & Selenium & $0.7 \mathrm{mcg}$ \\
\hline
\end{tabular}


Table 4. Active chemical constituents of Ginger (Kathi, 1999)

\begin{tabular}{ccc}
\hline \multirow{2}{*}{ Phenols } & Volatile & Others \\
\cline { 2 - 3 } & Sesquiterpenes & 6-dehydrogingerdione, \\
& & Galanolactone, \\
& Bisapolene, & Gingesulfonic acid, \\
Gingerols and Shogoals & Zingiberene, & Zingerone, \\
& Zingiberol, & Geraniol, \\
& Sesquiphellandrene, & Neral, \\
& Curcurmene & \\
& & Monoacyldigalactosylglycerols, \\
& Gingerglycolipids
\end{tabular}

Minerals content of ginger for ginger root (Ground) consists of calcium (114 mg per $100 \mathrm{~g}$ ), iron (19.8 mg per $100 \mathrm{~g})$, magnesium (214 mg per $100 \mathrm{~g}$ ), manganese (33.3 $\mathrm{mg}$ per $100 \mathrm{~g}$ ), phosphorus (168 $\mathrm{mg}$ per $100 \mathrm{~g}$ ), potassium (1320 mg per $100 \mathrm{~g}$ ), sodium (27 mg per $100 \mathrm{~g}$ ), and zinc (3.64 mg per $100 \mathrm{~g}$ ), and minerals contents for ginger root (raw) are calcium (16 mg per $100 \mathrm{~g})$, iron $(0.6 \mathrm{mg}$ per 100 g), magnesium ( $43 \mathrm{mg}$ per $100 \mathrm{~g}$ ), phosphorus (34 mg per $100 \mathrm{~g}$ ), potassium ( $415 \mathrm{mg}$ per $100 \mathrm{~g}$ ), sodium (13 mg per $100 \mathrm{~g}$ ), and zinc ( $0.34 \mathrm{mg}$ per $100 \mathrm{~g}$ ) (USDA, 2013). It was found that ginger contained 1.5\%-3\% essential oil, $2-12 \%$ fixed oil, $40-70 \%$ starch, $6-20 \%$ protein, $3-8 \%$ fibre, $8 \%$ ash, 9-12\% water, pungent principles, other saccharides, cellulose, colouring matter and trace minerals (Chan et al., 2009).

Ginger is called different names in different parts of the world such as Zingiberis rhizome, Shen jiany, Cochin, Asia ginger, Africa ginger and Jamaican ginger (Peter, 2000). Kala et al. (2016) stated that ginger oil also used as food flavouring agent in soft drink, as spices in bakery products, in confectionary items, pickles, sauces and as a preservatives. There is variability in the compounding of ginger products. The relative composition in the extraction of ginger is determined by species of ginger, maturity of the rhizome, climate in which the plants are grown, when harvested, and preparation method of the extract (Grzanna et al., 2005). Gaur et al. (2016) also reported that agro-climatic conditions are known to influence the production of secondary metabolites in ginger rhizome when same cultivar is grown in two different locations. Ginger is affected by leaf spots; leaves may have small, whitish spots with yellow edges; these get larger and spread, making the leaf yellow then brown, killing it. Early in the crop, it can cause severe losses. Fusarium spp., Rhizoctonia spp. and Pseudomonas solanacearum have been found in diseased leaves. Ginger propagation is usually performed with rhizome but has a lot of obstacles, the obstacles among other is the availability of good quality seed rhizome (Melati et al., 2016). Rhizome again, filled out, no wrinkles, bright shiny skin colour, and free of pests' attacks is characteristics of high-quality seed (Hasanah et al., 2004).

Medicinal uses and potential health benefits in traditional and modern medicine industry

Ginger has direct anti-microbial activity and thus can be used in treatment of bacterial infections (Tan and Vanitha, 2004). In traditional Chinese medicine, it is employed in colic and in atonic dyspepsia and used as a stimulant (Keys, 1985; Grant and Lutz, 2000; Sharma, 2017; Yilmaz et al., 2018). Ginger is regarded as a Yang herb, which can decrease Yin and nourish the body (Jittiwat and Wattanathorn, 2012). Mishra et al. (2012) also revealed that ginger in traditional Chinese medicine, characterized as spicy and hot, and it is claimed to warm the body and treat cold extremities, improves a weak and tardy pulse, address a pale complexion, and strengthen the body after blood loss. In traditional Chinese medicine is used as herbal therapy against several cardiovascular diseases (Wynn et al., 2001), based, on the historical usage of ginger as an antiemetic agent in the East Traditional Medicine. The antiemetic effect of ginger has been known as a treatment method in traditional medicine especially the Chinese and Iranian medicine (Eric Chan et al., 2011; Palatty et al., 2013; Naderi et al., 2016; Soltani et al., 2018). Sharma (2017) explained that many of herbs and plant extracts such as ginger is based on what has been used as part of traditional medicine systems and there is a large body of anecdotal evidence supporting their use and efficacy. Some other researchers emphasized that ginger plays an important role in Ayurvedic, Chinese, Arabic and African traditional medicines used to treat headaches, nausea, colds, arthritis, rheumatism, muscular discomfort and inflammation (Baliga et al., 2011; Dehghani et al., 2011). Recently, ginger rhizomes are used in traditional medicine as therapy against several cardiovascular diseases such as hypertension (Ghayur et al., 2005). Niksokhan et al. (2014) reported that ginger has been used in traditional medicine of Iran as an antiedema drug and is used for the treatment of various diseases including nausea, gastrointestinal disorders, respiratory disorders, athero-sclerosis, migraine, depression, gastric ulcer, cholesterol; and other benefits of giner are reducing pain, rheumatoid arthritis, anti-inflammatory, and antioxidant effects. Surh et al. (1998), and Manju and Nalini (2010) mentioned that ginger is one of the most widely used spices in India and has been utilized frequently in traditional oriental medicine for common cold, digestive disorders and rheumatism. Ursell (2000) and Oludoyin and Adegoke (2014) reported that ginger is a perennial plant with narrow, bright green, grass-like leaves, and it is cultivated in the tropics for its edible rhizomes and has been found to be useful for both culinary and medicinal purposes. Schwertner and Rios (2007) reported that the main components of ginger are 6-gingerol, 6-shogaol, 8-gingerol, and 10-gingerol and these constituents have previously been 
shown to exhibit strong antioxidant activity. 6-gingerol was reported as the most abundant bioactive compound in ginger with various pharmacological effects including antioxidant, analgesic, anti-inflammatory and antipyretic properties (Kundu et al., 2009; Dugasani et al., 2010). The shogaols can be partially transformed to paradols upon cooking or metabolized to paradols in the animals body after being consumed and absorbed by digestive system (Wei et al., 2017). Gingerol and shogaol in particular, is known to have anti-oxidant and anti-inflammatory properties (Kim et al., 2005) and it is shown in Fig. 1.

Ginger extract can remove disorders caused by oxidative stresses as a strong anti-oxidant. Studies have shown that extant phenolic compounds and anthocyanins including gingerols and the sugevals had many neuro protective effects such as analgesic effects, memory improvement, and learning caused by the aging process (Fadaki et al., 2017). For culinary purposes ginger is suitable for all dished both sweet such as drinks, puddings, apple pie, cakes, breads, candies, etc; and savoury such as soups, sauces, stews, savory puddings, grills, roasts, etc) (Oludoyin and Adegoke, 2014). Oludoyin and Adegoke (2014) stated that the active hypoglycemic component of ginger was not affected by heat, hence, the consumption of ginger in raw and cooked forms in different cuisines maybe an effective regimen in the management of diabetes. Similarly, the medicinal uses of ginger are enormous such as exert anti-microbial, antinausea (Portnoi et al., 2003), anti-pyretic (Suekawa et al., 1984), analgesic, anti-inflammatory, hypoglycaemic (Ojewole, 2006; Young et al., 2005), anti-ulcer, antiemetic (Mascolo et al., 1989), cardio tonic, anti-hypertensive (Ghayur and Gilani, 2005), hypolipidemic (Al-Amin et al., 2006), anti-platelet aggregation (Bordia et al., 1997) effects in both laboratory animals and human subjects. Turmeric is one of the main ingredients for curry powder, and used as an alternative to medicine and can be made into a drink to treat colds and stomach complaints (Chan et al., 2009). In folk medicine, turmeric has been used in lowering blood pressure and as tonic and blood purifier (The Wealth of India, 2001). Phytochemical investigation of several types of ginger rhizomes has indicated the presence of bioactive compounds, such as gingerols, which are antibacterial agents and shogaols, phenylbutenoids, diarylheptanoids, flavanoids, diterpenoids, and sesquiterpenoids (Sivasothy et al., 2011; El Makawy et al., 2019). It has been proved in
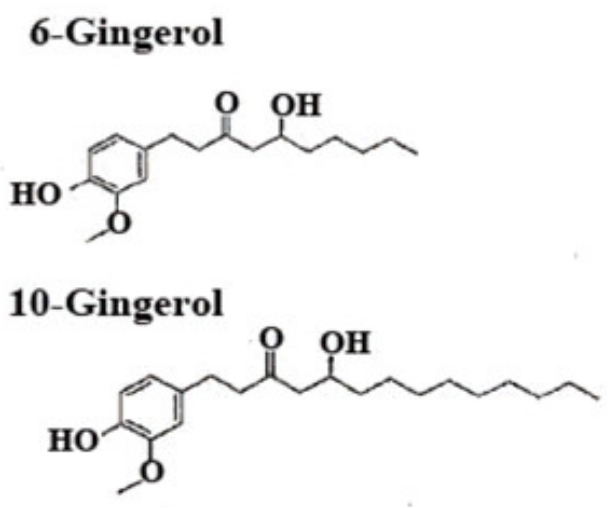

Fig. 1. Structure of 6-Gingerol, 8-Gingerol, 10-Gingerol and 6-Shogaol some researches that ginger leaves has great potential to be developed into functional foods and other health products, because it has higher antioxidant activity than rhizomes and flowers (Park et al., 2014). When compared to the Indian varieties, the Chinese ginger is low in pungency and is principally exported as preserves in sugar syrup or as sugar candy (Govindarajan, 1982).Semwal et al. (2015) reported that an infusion of ginger rhizomes with brown sugar is administered to relieve common colds, while scrambled eggs with powdered ginger is taken as a home remedy to reduce coughing in China. While, ginger is used in the United States as a remedy to alleviate motion sickness and morning sickness during pregnancy and to reduce hear cramps (Semwal et al., 2015). Furthermore, there are many studies that proved their beneficial effects against the symptoms of diseases, acting as anti-inflammatory, anti-tumour, anodyne, neuronal cell protective, anti-fungal and anti-bacterial agent (Mesomo et al., 2012; Yassen and Ibrahim, 2016). Various ginger compounds and extracts have been tested as antiinflammatory agents, where the length of the side chains determines the level of the effectiveness (Bartels et al., 2015). But, a combination of ginger extracts is more effective in decreasing inflammatory mediators than an individual compound (Lantz et al., 2007). The active ingredients in ginger are thought to reside in its volatile oils (Aldhebiani et al., 2017). The major ingredients in ginger oil are bisabolene, zingiberene, and zingiberol (Moghaddasi and Kashani, 2012). Some other scientists noted that the interest in ginger is endorsed to its several biologically active compounds content such as gingerol, shogaols, gingerdiol, gingerdione, $\alpha$-zingiberene, curcumin, and $\beta$-sesquiphellandrene (Zhao et al., 2011). Ginger has been part of the folk medicine and popular nutraceuticals (Bartels et al., 2015). Ginger consists of a complex combination of biologically active constituents, of which compounds gingerols, shogoals and paradols reportedly account for the majority of its anti-cancer inflammatory properties (Tjendraputra et al., 2001). 6-paradol was suggested as a therapeutic agent to effectively protect the brain after cerebral ischemia, likely by attenuating neuroinflammation in microglia (Gaire et al., 2015). Zinger officinale used as a condiment in several countries but also it acts as a treatment for ailments; for instance, gastrointestinal disorders, colds, arthritis, hypertension and migraines (White, 2007; Hosseini et al., 2015). Maghbooli et al. (2014) confirmed
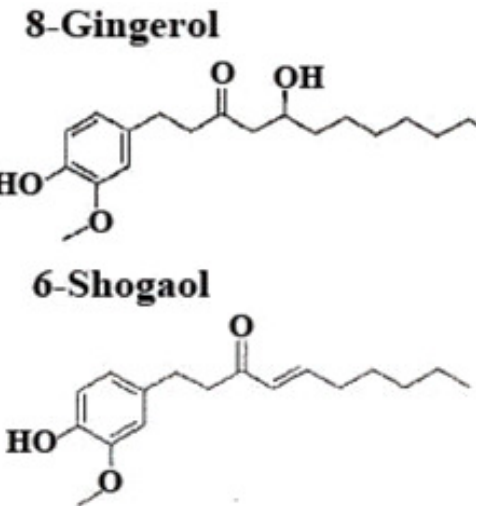
314

the efficiency of ginger powder in the therapy of common migraine attacks and its similarity to the antiepileptic drug. Many studies have reported that Ginger has useful effects to cancer prevention (Lee et al., 2008), also treatment of nausea and vomiting due to pregnancy and chemotherapy (Pongrojpaw et al., 2007; Ryan et al., 2012). The antispasmodic effect of Ginger is due to the blocked of cyclooxygenase and 5-lipoxygenase (van Breemen et al., 2011). Also, it has been reported that ginger lowers blood pressure through blockade of voltage dependent calcium channels (Ghayur and Gilani, 2005). Khaki et al. (74) reported that ginger has a protective effect against DNA damage induced by $\mathrm{H}_{2} \mathrm{O}_{2}$ and maybe promising in enhancing healthy sperm parameters. In Iran, traditionally ginger rhizome was used for enhancing male sexuality, regulating female menstrual cycle, and also reducing painful menstrual periods (Hafez, 2010). Adib Rad et al. (2018) reported that ginger as well as Novafen is effective in relieving pain in girls with primary dysmenorrhea, and treatment with natural herbal medicine, non-synthetic drug, is recommended to reduce primary dysmenorrhea. Karangiya et al. (2016) concluded that the supplementation of garlic improves the performance of broilers when added at the rate of $1 \%$ of broiler and can be a viable alternative to antibiotic growth promoter in the feeding of broiler chicken. Manju and Nalini (2010) found that ginger supplementation to 1,2-dimethyl hydrazine (DMH) treated rats inhibited colon carcinogenesis, as evidenced by the significantly decreased number and incidence of tumours; in addition ginger optimized tissue lipid peroxidation and antioxidant status in DMH treated rats. Dinesh et al. (2015) suggested that for growth promotion and management of soft rot disease in ginger, GRB35 $B$. amyloliquefaciens and GRB68 S. marcescens could be good alternatives to chemical measures; they also recommend the use of $B$. amyloliquefaciens for integration into nutrient and disease management schedules for ginger cultivation. Mahsani and Bukhari (2019) found that the extract of ginger rhizome have different effects on cells and anti-bodies of the immune system in smokers and non-smokers, although both benefited from enhancement of the thyroid gland. In their research, it has been found that ginger maybe beneficial for smokers with anemia, while for non-smokers, it may lead to a stronger antibody response or humoral immunity against infections. Vemuri et al. (2017) found that aqueous natural extracts mixtures (NE mix) prepared from common spice like ginger is a potential alternative therapeutic approach in certain types of cancer. Bartels et al. (2015) concluded that ginger maybe considered as a part of the symptomatic treatment of osteoarthritis $(\mathrm{OA})$, where the patient is motivated for trying this nutraceutical. Schnitzer et al. (2002) mentioned that evidences is now provided suggesting that it may have a place in the management of OA of the knee, and coated ginger extract maybe considered for this purpose in the future. Adib Rad et al. (2018) found that Ginger reduced menstrual pain, and it is effective in relieving pain in girls with primary dysmenorrhea; moreover, Drozdoz et al. (2012) mentioned that Ginger is a safe drug with minimal side effects. Singara et al. (2017) reported that ginger is an effective non pharmacological option for treating hyperemesis gravidarum with respect to the inherent heterogeneity of the available studies. Gholampour et al. (2017) found that ginger extract appears to exert protective effects against ferrous sulphate-induced hepatic and renal toxicity by reducing lipid peroxidation and chelating iron. Atashak $e t$ al. (2014) mentioned that 10 weeks of either ginger supplementation or progressive resistance training (PRT) protects against oxidative stress and therefore both of these interventions can be beneficial for obese individuals. Jittiwat and Wattanathorn (2012) demonstrated that ginger pharmacopuncture at GV20 can improve memory impairment following cerebral ischemia more rapidly than acupuncture, and one probable mechanism underlying this effect is improved oxidative stress. Yilmaz et al. (2018) found the positive effects of ginger in folliculogenesis and implantation. They have also found that ginger may enhance implantation in rats in long term with low dose. In other studies, the favourable outcomes have been reported on the positive effects of ginger on male infertility and sperm indices (Khaki et al., 2012; Ghlissi et al., 2013). Akinyemi et al. (2016) described that dietary supplementation with both types of rhizomes, namely ginger and turmeric, inhibited arginase activity and prevented hypercholesterolemia in rats that received a highcholesterol diet. In conclusion, these activities of ginger represent possible mechanisms underlying its use in herbal medicine to treat several cardiovascular diseases. Amri and Touil-Boukoffa (2016) concluded that Ginger has an important anti-hydatic effect in vitro, and this herbal product may protect against host's cell death by reducing the high levels of nitric oxide (NO). They finally suggest the promising use of ginger in the treatment of Echinococcus granulosus infection. Soltani et al. (2018) recommend administration of oral ginger one hour before operation to control the severity of postoperative nausea and vomiting (PONV) in patients undergoing laparoscopic cholecystetcomy. Daily et al. (2015) claimed that ginger root supplementation significantly lowers blood glucose and $\mathrm{HbAlc}$ levels, and when combined with dietary and lifestyle interventions, it may be an effective intervention for managing Type 2 diabetes mellitus. Islam et al. (2014) boiled ginger extracts can be used in food preparation as well as against pathogenic bacteria during active infection. Viljoen et al. (2014) suggested potential benefits of ginger in reducing nausea symptoms in pregnancy. They have found that ginger could be considered a harmless and possibly effective alternative option for women suffering from nausea and vomiting during pregnancy (NVP). Zaman et al. (2014) mentioned that ginger root extract significantly inhibited the gastric damage and ginger root showed significant anti-ulcerogenic activity in the model studied; it can be a promising gastro-protective agent. Willetts $e t$ al. (2003) concluded that ginger extract is a more effective treatment than placebo for nausea and retching during pregnancy. Yadav et al. (2016) demonstrated that ginger is one of the most commonly used spices and medicinal plants, and it is effective to improve diet induced metabolic abnormalities; however the efficacy of ginger on the metabolic syndrome associated kidney injury remains unknown. Naderi et al. (2016) stated that ginger powder supplementation at a dose of $1 \mathrm{~g} / \mathrm{d}$ can reduce inflammatory 
markers in patients with knee osteoarthritis, and it thus can be recommended as a suitable supplement for these patients. Mahmoud and Elnour (2013) discovered that ginger has a great ability to reduce body weight without inhibiting pancreatic lipase level, or affecting bilirubin concentration, with positive effect on increasing peroxisomal catalase level and HDL-cholesterol. Ebrahimzadeh Attari et al. (2015) revealed a minor beneficial effect of ginger powder supplementation on serum glucose and a moderate, significant effect on total cholesterol, as compared to the placebo. Malhotra and Singh (2003) also mentioned the effect of ginger on lowering cholesterol, and antihyperlipidemic agent, the role of ginger in the treatment of nausea and vomiting (anti-emetic), ginger possesses antiskin tumour promoting effects, and that the mechanism of such effects may involve inhibition of tumour promotercaused cellular, biochemical, and molecular changes (chemo-protective), anti-viral activity, anti-motion and anti-nauseant effects, anti-inflammatory, diminishing or eliminating the symptoms of hyperemesis gravidarum, ginger influence on exert abortive and prophylactic effects in migraine headache without any side effects and antiulcerogenic, Ginger and its constituent play pharmacological effects in cancer management via modulation of molecular mechanism, and the mechanism consist of inhibition of VEGF, activation of Bax, inhibition of Lypoxygenase, activation o P53, inhibition of Interlukin, inhibition of $\mathrm{Bcl} 2$ and Survivin, inhibition of Cycloxygenase, inhibition of IFN- $\gamma$, suppression of TNF and NF-kB and activation of G0/G1 phase (Rahmani et al., 2014). Accumulating evidence suggests that many dietary factors may be used alone or in combination with traditional chemotherapeutic agents to prevent or treat disease, and ginger is example of medicinal plants which is gaining popularity amongst modern physicians (Sakr and Badawy, 2011). Gagnier et al. (2006) provide an excellent framework for the development of future trials that focus on providing satisfactory answers to issues relating to the efficacy of $Z$. officinale to ameliorate different types of pain, as well as, dosing strategies, treatment duration, safety, and cost effectiveness.

\section{Conclusions}

Ginger is used worldwide as a cooking spice, condiment and herbal remedy, and it is also extensively consumed as a flavouring agent. Ginger, a plant in the Zingiberaceae family, is a culinary spice that has been as an important herb in traditional Chinese medicine for many centuries. More than 60 active constituents are known to be present in ginger, which have been broadly divided into volatile and non-volatile compounds. Hydrocarbons mostly monoterpenoid hydrocarbons and sesquiterpene include the volatile component of ginger and impart distinct aroma and taste to ginger. Non-volatile compounds include gingerols, shogaols, paradols, and also zingerone. The active ingredients like gingerols, shogaols, zingerone, and so forth present in ginger exhibit antioxidant activity. Among gingerols and shogaol the major pungent components in the rhizome are 6-gingerol and 6-shogaol. Gingerol, the active constituent of ginger has been isolated and studied for pharmacological and toxic effects. Fresh ginger has been used for treatment of nausea, cold-induced disease, colic, asthma, cough, heart palpitation, swellings, dyspepsia, loss of appetency and rheumatism. Medicinal properties associated with ginger are, anti-inflammatory properties, antithrombotic properties, cholesterol-lowering properties, blood pressure-lowering properties, anti-microbial properties, anti-oxidant properties, anti-tumor properties, and hypoglycaemic properties. Consumption of ginger also has beneficial effects on heart disease, cancer, hypertension, obesity, diabetes, osteoarthritis, and bacterial infections. Ginger is an herbal, easily available, low price medication which is associated with low risk can be substituted for chemical, scarce and expensive drugs. Based on other scientific literature, ginger demonstrates some promising health benefits, and more information gleaned from additional clinical studies will help confirm whether ginger's multiple health benefits can be significantly realized in humans. Herbal remedies and other nutraceuticals are increasingly and extensively used by a substantial part of the population. To sum up, treatment with natural herbal medicine especially ginger, non-synthetic drug is recommended.

\section{Conflict of Interest}

The authors declare that there are no conflicts of interest related to this article.

\section{References}

Adib Rad H, Basirat Z, Bakouei F, Moghadamnia AA, Khafri S, Farhadi Kotenaei Z, ... Kazemi S (2018). Effect of ginger and Novafen on menstrual pain: a cross-over trial. Taiwanese Journal of Obstetrics and Gynecology 57(6):806-809.

Afzal M, Al-Hadidi D, Menon M, Pesek J, Dhami MS (2001). Ginger: an ethno-medical, chemical and pharmacological review. Drug Metabolism and Drug Interactions 18(3-4):159-190.

Akinyemi AJ, Adedara IA, Thome GR, Morsch VM, Rovani MT, Mujica LKS, ... Schetinger MRC (2015). Dietary supplementation of ginger and turmeric improves reproductive function in hypertensive male rats. Toxicology Reports 2:1357-1366.

Akinyemi AJ, Oboh G, Ademiluyi AO, Boligon AA, Athayde ML (2016). Effect of two ginger varieties on arginase activity in hypercholesterolemic rats. Journal of Acupuncture and Meridian Studies 9(2):80-87.

Al-Amin ZM, Thomson M, Al-Qattan KK, Peltonen-Shalaby R, Ali $\mathrm{M}(2006)$. Anti-diabetic and hypoglycemic properties of ginger (Zingiber officinale) in streptozotocin-induced diabetic rats. British Journal of Nutrition 96(4):660-666.

Aldhebiani AY, Elbeshehy EKF, Baeshen AA, Elbeaino T (2017). Inhibitory activity of different medicinal extracts from Thuja leaves, ginger roots, Harmal seeds and turmeric rhizomes against fig leaf mottleassociated virus 1 (FLMaV-1) infecting figs in Mecca region. Saudi Journal of Biological Sciences 24(4):936-944.

Ali BH, Blunden G, Tanira MO, Nemmar A (2008). Some phytochemical, pharmacological and toxicological properties of ginger (Zingiber officinale Roscoe): a review of recent research. Food and Chemical Toxicology 46(2):409-420. 
316

Alakali J, Irtwange SV, Satimehin A (2009). Moisture adsorption characteristics of ginger slices. Food, Science and Technology 29(1):155164.

Amri M, Touil-Boukoffa C (2016). In vitro anti-hydatic and immunomodulatory effects of ginger and [6]-gingerol. Asian Pacific Journal of Tropical Medicine 9(8):749-756.

Atashak S, Peeri M, Azarbayjani MA, Stannard SR (2014). Effects of ginger (Zingiber officinale Roscoe) supplementation and resistance training on some blood oxidative stress markers in obese men. Journal of Exercise Science and Fitness 12(1):26-30.

Baliga MS, Haniadka R, Pereira MM, DSouza JJ, Pallaty PL, Bhat HP, Popuri $S$ (2011). Update on the chemo preventive effects of ginger and its phytochemicals. Critical Reviews in Food Science and Nutrition 51(6):499-523.

Bartels EM, Folmer VN, Bliddal H, Altman RD, Julh C, Tarp S, ... Christensen R (2015). Review, efficacy and safety of ginger in osteoarthritis patients: a meta-analysis of randomized placebo-controlled trials. Osteoarthritis and Cartilage 23(1):13-21.

Blumenthal M, Goldberg A, Brinckmann J (2000). Herbal medicine: expanded commission E monographs. Austin TX: American Botanical Council; Newton MA: Integrative Medicine Communications, pp 153-159.

Bordia A, Verma SK, Srivastava KC (1997). Effect of ginger (Zingiber officinale Rosc.) and fenugreek (Trigonella foenumgraecum L.) on blood lipids, blood sugar and platelet aggregation in patients with coronary artery disease. Prostaglandins Leukotrienes and Essential Fatty Acids 56(5):379-384.

Chan EWC, Lim Y, Wong S(2009).Effects of different drying methods on the antioxidant properties of leaves and tea of ginger species. Food Chemistry 113(1):166-172.

Daily JW, Yang M, Kim DS, Park S (2015). Efficacy of ginger for treating Type 2 diabetes: A systematic review and meta-analysis of randomized clinical trials.Journal ofEthnic Food 2(1):36-43.

Dehghani I, Mostajeran A, Asghari G (2011).In vitro and in vivo production of gingerols and zingiberene in ginger plant (Zingiber officinale Roscoe). Iranian Journal of Pharmaceutical Sciences 7(2):129-133.

DhanikJ, Arya N,Nand V(2017). A review on Zingiber officinale. Journal of Pharmacognosy and Phytochemistry 6(3):174-184.

Dinesh R, Anandaraj M, Kumar A, Bini YK, Subila KP, Aravind R (2015). Isolation, characterization, and evaluation of multi-trait plant growth promoting rhizobacteria for their growth promoting and disease suppressingeffects on ginger. Microbiological Research 173:3443.

Drozdov VN, Kim VA, Tkachenko EV, Varvanina GG (2012). Influence of a specific ginger combination on gastropathy conditions in patients with osteoarthritis of the knee or hip. The Journal of Alternative and Complementary Medicine 18(6):583-588.

Dugasani S, Pichika MR, Nadarajah VD, Balijepalli MK, Tandra S, Korlakunta JN (2010). Comparative antioxidant and antiinflammatory effects of [6]-gingerol, [8]-gingerol, [10]-gingerol and [6]shogaol.Journal of Ethnopharmacology 172(2):525-520.

Ebrahimzadeh Attari V, Mahluji S, Asghari Jafarabadi M, Ostadrahimi A (2015). Effects of supplementation with Ginger (Zingiber officinale Roscoe) on serum glucose, lipid profile, and oxidative stress in obese women: a randomized, placebo-controlled clinical trial. Pharmaceutical Sciences 21(4):184-191.

El Makawy AI, Ibrahim FM, Mabrouk DM, Ahmed KA, Ramadan MF (2019).Effect of antiepileptic drug(Topiramate) and cold pressed ginger oil on testicular genes expression, sexual hormones and histopathological alterations in mice. Biomedicine \& Pharmacotherapy 110:409-419.

El Sayed SM, Moustafa RA (2016). Effect of combined administration of ginger and cinnamon on high fat diet induced hyperlipidemia in rats. Journal of Pharmaceutical, Chemical and Biological Sciences 3(4):561572.

Elzebroek ATG, Wind K(2008). Guide to cultivated plants. CAB International Wallingford, Oxfordshire, UK, pp 276-279.

Eric Chan WC, Lim YY, Wong SK (2011). Antioxidant properties of ginger leaves: an overview. Free Radicals Research 1:6-16.

Fadaki F, Modaresi M, Sajjadian I (2017). The effects of ginger extract and diazepam on anxiety reduction in animal model. Indian Journal of Pharmaceutical Education and Research 51(3):S159-S162.

GagnierJJ, Boon H, Rochon P, Barnes J, Moher D, Bombardier CB (2006). Reporting randomized controlled trials of herbal interventions: An elaborated CONSORT statement. Annals of Internal Medicine 155(5):364367.

Gaire BP, Kwon OW, Park SH, Chun KH, Kim SY, Shin DY, Choi JW (2015). Neuroprotective effect of 6-paradol in focal cerebral ischemia involves the attenuation of neuroinflammatory responses in activated microglia. PLoSOne 10(3):e0120203.

Gaur M, Das A, Sahoo RK, Mohanty S, Joshi RK, Subudhi E (2016). Comparative transcriptome analysis of ginger variety Suprabha from two different agro-dimatic zones of Odisha. Genomics Data 9:42-43.

Ghayur MN, Gilani AH (2005). Ginger lowers blood pressure through blockade of voltage-dependent calcium channels. Journal of Cardiovascular Pharmacology 45(1):7480.

Ghayur MN, Gilani AH, Afridi MB (2005). Cardiovascular effects of ginger aqueous extract and its phenolic constituents are medicated through multiple pathways. Vascular Pharmacology 43(4):234241.

Ghlissi Z, Atheymen R, Boujbiha MA, Sahnoun Z, Makni Ayedi F, Zeghal $\mathrm{K}, . .$. Hakim A (2013). Antioxidant and androgenic effects of dietary ginger on reproductive function of male diabetic rats. International Journal of Food Sciences and Nutrition 64(8):974-978.

Gholampour F, Behzadi Ghiasabadi F, Owji SM, VatanparastJ (2017). The protective effect of hydroalcoholic extract of ginger (Zingiber officinale Rosc.) against iron-induced functional and histological damages in rat liver and kidney. Avicenna Journal of Phytomedicine 7(6):542-553.

Govindarajan VS (1982). Ginger-chemistry, technology, and quality evaluation: part 1. Critical Reviews in Food Science and Nutrition 17(1):1-96

Grant KL, Lutz RB (2000). Ginger. American Journal of Health-System Pharmacy 57(10):945-947.

Grzanna R, LindmarkL, Frondoza CG (2005). Ginger-an herbal medicinal product with broad anti-inflammatory actions. Journal of Medicinal Food 8(2):125-132.

Hafez DA (2010). Effect of extracts of ginger roots and cinnamon bark on fertility of male diabetic rats. Journal of American Science 6(10):940947. 
Hasanah M, Sukarman, Rusmin D (2004). Ginger seed production technology. Technology Developments Spices and Medicinal 16(1):916.

Hosseini A, Mirazi N (2015). Alteration of pentylenetetrazole-induced seizure threshold by chronic administration of ginger (Zingiber officinale) extract in male mice. Pharmaceutical Biology 53(5):752-757.

Islam K, Rowsni AA, Khan MM, Kabir MS (2014). Antimicrobial activity of ginger (Zingiber officinale) extracts against food-borne pathogenic bacteria. International Journal of Science, Environment and Technology 3(3):867-871.

Jittiwat J, Wattanathorn J (2012). Ginger pharmacopuncture improves cognitive impairment and oxidative stress following cerebral ischemia. Journal of Acupuncture and Meridian Studies 5(6):295-300.

Kala C, Ali SS, Chaudhary S (2016). Comparative pharmacognostical evaluation of Costus speciosus (Wild Ginger) and Zingiber officinale (Ginger) rhizome. International Journal of Current Pharmaceutical Research 8(4):19-23.

Karangiya VK, Savsani HH, Patil SS, Garg DD, Murthy KS, Ribadiya NK, Vekariya SJ (2016). Effect of dietary supplementation of garlic, ginger and their combination on feed intake, growth performance and economics in commercial broilers. Veterinary World 9(3):245-250.

Kathi JK (1999). Ginger (Zingiber officinale). The Longwood Herbal Task Force (http://www.mcp.edu/herbal/defaulthtm) and The Centre for Holistic Pediatric Education and Research (http://www.childrenshospital.org/holistic/).

Keys JD (1985). Chinese herbs ( $\left.3^{\text {rd }} \mathrm{Edn}\right)$. Charles E Tuttle Company, Inc, Japan pp 77-78.

Khaki A, Farnam A, Badie AD, NikniazH (2012). Effects of onion (Allium cepa) and ginger (Zingiber officinale) on sexual behaviour of rat after inducing antiepileptic drug (lamotrigine). Balkan Medical Journal 3:236-242.

Kim SO, Kundu JK, Shin YK, Park JH, Cho MH, Kim TY, Surh YJ (2005). [6]-Gingerol inhibits COX-2 expression by blocking the activation of p38 MAP kinase and NF-kappaB in phorbol esterstimulated mouse skin. Oncogene 24(15):2558-2567.

Kochhar A (1981). Tropical crops. A textbook of economic botany. London: McMillan Press, pp 268-270.

Kundu JK, Surh YJ (2009). Molecular basis of chemoprevention with dietary phytochemicals: redox-regulated transcription factors as relevant targets. Phytochemistry Reviews 8(2):333-347.

Langner E, Greifenberg S, Gruenwald J (1998). Ginger: history and use. Advances in Therapy 15(1):25-44.

Lantz RC, Chen GJ, Sarihan M, Solyom AM, Jolad SD, Timmermann BN (2007). The effect of extracts from ginger rhizome on inflammatory mediator production. Phytomedicine 14(2-3):123-128.

LeeSH, Cekanova M, Baek SJ (2008). Multiple mechanisms are involved in 6-gingerol-induced cell growth arrest and apoptosis in human colorectal cancer cells. Molecular Carcinogenesis 47(3):197-208.

Lister M (2003). Herbal medicine in pregnancy. Complement nursing and midwifery.9(1):49.

Maghbooli M, Golipour F, Esfandabadi MA, Yousefi M (2014). Comparison between the efficacy of ginger and sumatriptan in the ablative treatment of the common migraine. Phytotherapy Research
28(3):412-415

Mahassni SH, Bukhari OA (2019). Beneficial effects of an aqueous ginger extract on the immune system cells and antibodies, hematology, and thyroid hormones in male smokers and non-smokers. Journal of Nutrition \& Intermediary Metabolism 15:10-17.

Mahmoud RH, Elnour WA(2013). Comparative evaluation of the efficacy of ginger and orlistat on obesity management, pancreatic lipase and liver peroxisomal catalase enzyme in male albino rats. European Review for Medical and Pharmacological Sciences 17(1):75-83.

Malhotra S, Singh AP (2003). Medicinal properties of ginger (Zingiber officinale Rosc.). Natural Product Radiance 2(6):296-301.

Manju V, Nalini N (2010). Effect of ginger on lipid peroxidation and antioxidant status in 1,2-dimethyl hydrazine induced experimental colon carcinogenesis. Journal of Biochemical Technology 2(2):161-167.

Mascolo N, Jain R, Jain SC, Capasso F (1989). Ethno pharmacologic investigation of ginger (Zingiber officinale). Journal of Ethnopharmacology 27(1-2):129-140.

Melati, Ilyas S, Palupi ER, Susila AD (2016). Growth, yield and quality of ginger from produced through early senescence. International Journal of Applied Science and Technology 6(1):21-28.

Memudu AE, Akinrinade ID, Ogundele OM, Duru F (2012). Investigation of the androgenic activity of ginger (Zingiber officinale) on the histology of the testis of adult sparague dawley rats. Journal of Medicine and Medical Sciences 3(11):697-702.

Mesomo MC, Scheer AP, Elisa P, Ndiaye PM, Corazza ML (2012). Ginger (Zingiber officinale $\mathrm{R}$ ) extracts obtained using supercritical $\mathrm{CO}_{2}$ and compressed propane: kinetics and antioxidant activity evaluation. The Journal of Supercritical Fluids 71:102-109.

Mishra RK, Kumar A, Kumar A (2012). Pharmacological activity of Zingiber officinale. International Journal of Pharmaceutical and Chemical Sciences 1(3):1422-1427.

Moghaddasi MS, KashaniHH (2012). Ginger (Zingiber officinale): a review. Journal of Medicinal Plants Research 6(26):4255-4258.

Naderi Z, Mozaffari-Khosravi H, Dehghan A, Nadjarzadeh A, Fallah Huseini $\mathrm{H}(2016)$. Effect of ginger powder supplementation on nitric oxide and C-reactive protein in elderly knee osteoarthritis patients: A 12week double-blind randomized placebo-controlled clinical trial. Journal of Traditional and Complementary Medicine 6(3):199-203.

Niksokhan M, Hedarieh N, Maryam N, Masoomeh N (2014). Effect of hydro-alcholic extract of Pimpinella anisum seed on anxiety in male rat. Journal of Gorgan University Medical Science 16(4):28-33.

Nour AH, Yap SS, Nour AH (2017). Extraction and chemical compositions of Ginger (Zingiber officinale Roscoe) essential oils as cockroaches repellent. Australian Journal of Basic and Applied Sciences 11(3):1-8.

Ogbaji PO, Li J, Xue X, Shahrajabian MH, Egrinya EA (2018). Impact of bio-fertilizer or nutrient solution on spinach (Spinacea oleracea) growth and yield in some province soils of P.R. China. Cercetari Agronomice in Moldova2(174):43-52.

Ojewole JAO (2006). Analgesic, anti-inflammatory and hypogycemic effects of ethanol extract of $Z$ ingiber officinale (Roscoe) rhizomes in mice and rats. Phytotherapy Research 20(9):764772. 
318

Oludoyin AP, Adegoke SR (2014). Effect of ginger (Zingiber officinale) extracts on blood glucose in normal and streptozotocin-induced diabetic rats. International Journal of Clinical Nutrition 2(2):32-35.

Palatty PL, Haniadka R, Valder B, Arora R, Baliga MS (2013). Ginger in the prevention of nausea and vomiting: a review. Critical Reviews in Food Science and Nutrition 53(7):659-669.

Park GH, Park JH, Song HM, Eo HJ, Kim MK, Lee JW, ... Jeong JB (2014). Anti-cancer activity of ginger (Zingiber officinale) leaf through the expression of activating transcription factor 3 in human colorectal cancer cells. BMC Complementary and Alternative Medicine 14(1):408.

Peter KV (2000). Handbook of herbs and spices. RC Press Wood Head Publishing, Cambridge, pp 319.

Pongrojpaw D, Somprasit C, Chanthasenanont A (2007). A randomized comparison of ginger and dimenhydrinate in the treatment of nausea and vomiting in pregnancy. Journal-Medical Association of Thailand 90(9):1703.

Portnoi G, Chng LA, Karimi-Tabesh L, Koren G, Tan MP, Einarson A (2003). Prospective comparative study of the safety and effectiveness of giner for the treatment of nausea and vomiting in pregnancy. American Journal ofObstetrics and Gynaecology 189(5):1374-1377.

Rahmani AH, Al Shabrmi FM, Aly SM (2014). Active ingredients of ginger as potential candidates in the prevention and treatment of diseases via modulation of biological activities. International Journal of Physiology, Pathophysiology and Pharmacology 6(2):125-136.

Ryan JL, Heckler CE, Roscoe JA, Dakhil SR, Kirshner J, Flynn PJ, ... Morrow GR (2012). Ginger (Zingiber officinale) reduces acute chemotherapy-induced nausea: a URCCCCOP study of 576 patients. Support Care Cancer 20(7):1479-1489.

Sakr SA, Badawy GM (2011). Effect of ginger (Zingiber officinale R) on metiram-inhibited spermatogenesis and induced apoptosis in albino mice.Journal of Applied Pharmaceutical Science 1(4):131-136.

Sandeep S (2017). Commentary on therapeutic role of ginger (Zingiber officinale) as medicine for the whole world. International Journal of Pharmacognosy and Chinese Medicine 1(1):1-3.

Schnitzer TK (2002). Update of ACR guidelines for osteoarthritis: role of the coxibs. Journal of Pain and Symptom Management 23(4):S24S30.

Schwertner HA, Rios DC (2007). High-performance liquid chromatographic analysis of 6-gingerol, 8-gingerol, 10-gingerol, and 6shogal in ginger containing dietary supplements, spices, teas, and beverages. Journal ofChromatography B 856(1-2):41-47.

Sekiwa Y, Kubota K, Kobayashi A (2000). Isolation of novel gycosides from ginger and their antioxidative activity. Journal of Agricultural and Food Chemistry48(2):373-379.

Semwal RB, Semwal DK, CombrinckS, Viljoen AM (2015). Gingerols and shogaols: Important nutraceutical principles from ginger. Phytochemistry 117:554-568.

Shahrajabian MH, Sun W, Cheng Q (2018). A review of Goji berry (Lycium barbarum) in traditional Chinese medicine as a promising organic superfood and superfruit in modern industry. Academia Journal of Medicinal Plants 6(12):437-445.

Shahrajabian MH, Sun W, Cheng Q (2019a). The influence of traditional Iranian and Chinese medicine on western and Islamic countries. Asia
Journal of Medical and Biological Research 5(2):9499.

Shahrajabian MH, Sun W, Cheng Q (2019b). Modern pharmacological actions of longan fruits and their usages in traditional herbal remedies. Journal of Medicinal Plants Studies 7(4):179-185.

Shahrajabian MH, Khoshkharam M, Zandi P, Sun W, Cheng Q (2019c). Jujube, a super-fruit in traditional Chinese medicine, heading for modern pharmacological science. Journal of Medicinal Plants Studies 7(4):173-178.

Shahrajabian MH,Sun W, ChengQ(2019d). A review of ginsengspecies in different regions as a multipurpose herb in traditional Chinese medicine, modern herbology and pharmacological science. Journal of Medicinal Plants Research 13(10):213-226.

Shahrajabian MH, Sun W, Cheng Q (2019e). Traditional Chinese medicine and agriculture; organic life and sustainability for future. GSC Biological and Pharmaceutical Sciences 7(01):091-095.

Shahrajabian MH, Khoshkharam M, Zandi P, Sun W, Cheng Q (2020). The influence of temperatures on germination and seedling growth of pyrethrum (Tanacetum cineraiifolium) under drought stress. International Journal of Advanced Biological and Biomedical Research 8(1):29-39.

Sharma Y (2017). Ginger (Zingiber officinale)-an elixir of life a review. The Pharma Innovation Journal 6(10):22-27.

Shirin Adel PR, Prakash J (2010). Chemical composition and antioxidant properties of ginger root (Zingiber officinale).JMPR 4(23):2674-2679.

Sinagra E, Matrone R, Gullo G, Catacchio R, Renda E, Tardino S, ... Raimondo D (2017). Clinical efficacy of ginger plus $B_{6}$ vitamin in hyperemesis gravidarum: report of two cases. Gastroenterol Hepatol Open Access 6(1):00182.

SingRP, Gangadharappa HV, Mruthunjaya K (2017). Ginger: a potential neutraceutical: an updated review. International Journal of Pharmacognosy and Phytochemical Research 9(9):1227-1238.

Sivasothy Y, Wong KC, Hamid A, Eldeen IM, Sulaiman SF, Awang K (2011). Essential oil of Zingiber officinale var. rubrum Theilade and their antibacterial activities. Journal of Food Chemistry 124(2):514517.

Soltani E,Jangjoo A, Afzal Aghaei M, Dalili A (2018). Effects of preoperative administration of ginger (Zingiber officinale Roscoe) on postoperative nausea and vomiting after laparoscopic cholecystectomy. Journal of Traditional and Complementary Medicine 8(3):387-390.

Suekawa M, Ishige A, Yuansa K, Sudo K, Aburada M, Hosoya E (1984). Pharmacological studies on ginger pharmacological actions of pungent constituents of 6-gingerol and 6-shogaol. Journal of Pharmacobiodynamics 7(11):836-848.

Surh YJ, Loe E, Lee JM (1998). Chemo preventive properties of some pungent ingredients present in red pepper and ginger. Mutation Research/Fundamental and Molecular Mechanisms of Mutagenesis 402(1-2):259-267.

Tan BKH, Vanitha J (2004). Immunomodulatory and antibacterial effects of some traditional Chinese medicinal herbs: a review. Current Medicinal Chemistry 11:1423-1430.

The Wealth of India (2001). A dictionary of Indian raw materials and industrial products, first supplement series vol. II, New Delhi: National Institute of Science Communication CSIR 264293.

Tjendraputra E, Tran VH, Liu-Brennan D, Roufogalis BD, Duke CC 
(2001). Effect of ginger constituents and synthetic analogues on cyclooxygenase-2 enzyme in intact cells. Bioorganic Chemistry 29(3):156-163.

Toda K, Hitoe S, Takeda S, Shimoda H (2016). Black ginger extract increases physical fitness performance and muscular endurance by improvinginflammation and energy metabolism. Heliyon 2(5):e00115.

Ursell A (2000). The complete guide to healing foods. Dorling Kindersley Ltd, London, pp 112-114.

USDA (2013). National Nutrient Database for Standard Reference Release 26 Full Report (All Nutrients) Nutrient data for 2013, Spices, Ginger.

Van Breemen RB, Tao Y, Li W (2011). Cyclooxygenase-2 inhibitors in ginger (Zingiber officinale). Fitoterapia 82(1):38-43.

Vasala PA (2004). Ginger. (ed) Peter, K. V.Handbook of Herbs and Spices. Vol 1. Cochin, India

Vemuri SK, Banala RR, Subbaiah GPV, Srivastava SK, Reddy AVG, Malarvili T (2017). Anti-cancer potential of a mix of natural extracts of turmeric, ginger and garlic: A cell-based study. Egyptian Journal of Basic and Applied Sciences 4(4):332-344.

Viljoen E, Visser J, Koen N, Musekiwa A (2014). A systematic review and meta-analysis of the effect and safety of ginger in the treatment of pregnancy-associated nausea and vomiting. Nutrition Journal 13(20):114.

Wei CK, Tsai YH, Korinek M, Hung PH, El-Shazly M, Cheng YB, ... ChangFR(2017). 6-Paradol and 6-shogaol, the pungent compounds of ginger, promote glucose utilization in adipocytes and myotubes, and 6paradol reduces blood glucose in high-fat diet-fed mice. International Journal of Molecular Sciences 18(1):168.

White B (2007). Ginger: an overview. American Family Physician 75(11):1689-1691.
Wolletts K, Ekangaki A, Eden JA (2003). Effect of a ginger extract on pregnancy-induced nausea: a randomised controlled trial. Australian and New ZealandJournal ofObstetrics and Gynaecology 43(2):139-144.

Wynn SG, Luna SPL, Liu H (2001). Global acupuncture research: previously untranslated studies. Studies from Brazil. Veterinary Acupuncture: Ancient Art to Modern Medicine, St Louis: Mosby, pp 53-57

Yadav S, Sharma PK, Aftab Alam Md (2016). Ginger medicinal and uses and benefits. European Journal of Pharmaceutical and Medical Research 3(7):127-135.

Yassen D, Ibrahim AE (2016). Antibacterial activity of crude extracts of ginger (Zingiber officinale Roscoe) on Escherichia coli and Staphylococcus aureus: a study in vitro. Indo American Journal of Pharmaceutical Research 6(06):5830-5835.

Yilmaz N, Seven B, Timur H, Yorganci A, Inal HA, Kalem MN, ... Bilezikci B (2018). Ginger (Zingiber officinale) might improve female fertility: A rat model.Journal of the Chinese Medical Association 81(10):905-911.

Young HV, Luo YL, Chang HY, Haieh WC, Liao JC, Peng WC (2005). Analgesic and anti-inflammatory activities of 6-gingerol. Journal of Ethnopharmacology 96(1-2):207-210.

Zaman SU, Mirje MM, Ramabhimaiah S (2014). Evaluation of the antiulcerogenic effect of Zingiber officinale (Ginger) root in rats. International Journal of Current Microbiology and Applied Sciences 3(1):347-354.

Zhao X, Zingiber B, Yang WR, Yang Y, Wang S, Jiang Z, Zhang GG (2011). Effects of ginger root (Zingiber officinale) on laying performance and antioxidant status of laying hens and on dietary oxidation stability. Poultry Science 90(8):1720-1727. 